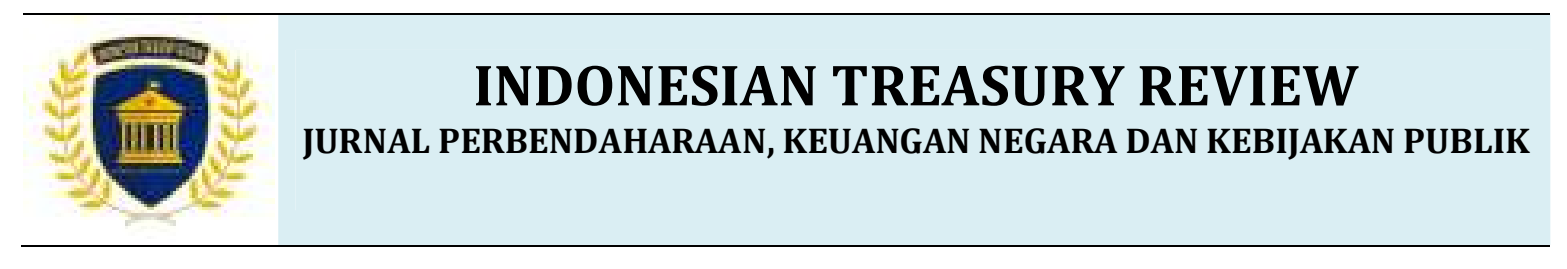

\title{
Efisiensi Dana Bos Antar Provinsi di Indonesia: Apa Yang Memengaruhi?
}

Irsyan Maududy

Badan Kebijakan Fiskal

Abrar Aulia

Creco Consulting and Research

Alamat Korespondensi: irsyanmh@gmail.com

INFORMASI ARTIKEL

Diterima Pertama

15 Juni 2018

Dinyatakan Diterima

06 Desember 2018

KATA KUNCI:

Dana BOS, Efisiensi, Data Envelopment Analysis

(DEA), Panel Data Tobit

KLASIFIKASI JEL:

I25, P36, E62

\begin{abstract}
ABSTRAK
Setelah reformasi, Pemerintah Indonesia menetapkan sektor pendidikan sebagai sakah satu hal yang diiprioritaskan dalam kebijakan fiskal dengan adanya mandatory spending pada sektor sebesar 20\% dari total APBN. Prioritas pertama kebijakan pendidikan adalah meningkatkan school enrollment ratio di Indonesia dengan penggunaan Dana Bantuan Operasional Sekolah (BOS) dalam menunjang program wajib belajar sembilan tahun. Studi ini bertujuan untuk mengukur efisiensi anggaran BOS terhadap indikator yang merupakan tujuan dari penganggaran tersebut. Dalam mengukur efisiensi, penulis menggunakan metode Data Envelopment Analysis (DEA) dengan output untuk anggaran BOS adalah Angka Partisipasi Murni (APM), nilai Ujian Nasional, angka putus sekolah, angka transisi ke jenjang berikutnya, dan persentase ruang kelas dengan kondisi baik. Studi ini juga melihat determinan dari efisiensi tersebut dengan menggunakan Tobit Estimation Technique serta variabel pertumbuhan PDRB, kualitas guru, tingkat kemiskinan, Indeks Pembangunan Manusia (IPM), dan cakupan sekolah sebagai determinan. Dengan menggunakan data 33 provinsi di Indonesia dari tahun 2014 sampai 2017, studi ini menemukan bahwa secara umum tingkat efisiensi pada jenjang pendidikan SD dan SMP sudah cukup efisien. Lebih lanjut, kualitas guru, IPM, dan tingkat kemiskinan merupakan variabel yang memiliki pengaruh terhadap efisiensi pengunaan dana BOS.
\end{abstract}

After reformation, Government of Indonesia has put education sector as the most prioritized area in fiscal policy with mandatory spending on this sector has reached $20 \%$ of State Budget. The first priority of education policy is to increase enrollment ratio in Indonesia by using School Operational Assistance Fund (BOS) to support the nine-year compulsory education program. This study aims to measure BOS fund efficiency to it's objectives. We used Data Envelopment Analysis (DEA) method to measure public spending efficiency with output for BOS fund is Net Enrollment Ratio, National Exam Score, drop out rate, transition rate and percentage of classroom with good condition. The study also looks at the determinants of efficiency using Tobit Estimation Technique with GDP growth, teachers quality, poverty rate, Human Development Index (HDI), and school coverage as determinants. Using data from 33 provinces in Indonesia from 2014 to 2017, this study found that in general the level of efficiency at the primary and junior secondary levels of education was quite efficient. Furthermore, the quality of teachers, the HDI, and the level of poverty are variables that have an influence on the efficiency of the use of BOS funds. 


\section{PENDAHULUAN}

Pembangunan ekonomi dan kualitas hidup manusia sangat ditentukan oleh faktor pendidikan. Penelitian mengenai pentingnya pendidikan sebagai intrumen bagi kemajuan suatu negara pun sudah banyak dilakukan. Hanushek dan Wobmann (2010) menemukan hubungan yang positif antara years of schooling dan long-run economic growth. Setidaknya, menurut Hanushek dan Wobmann (2010), ada tiga mekanisme pendidikan mempengaruhi pertumbuhan ekonomi. Pertama, pendidikan meningkatkan kualitas modal manusia yang akan masuk ke tenaga kerja sehingga meningkatkan produktivitas tenaga kerja dan pada akhinya meningkatkan tingkat output atau GDP sesuai dengan riset Mankiw et al. (1992). Kedua, pendidikan akan meningkatkan kapasitas inovasi dalam perekonomian sehingga akan menciptakan teknologi baru, sesuai dengan teori endogenous growth yang dikembangkan oleh Romer (1990). Ketiga, pendidikan membuat transmisi pengetahuan (sharing knowledge) yang perlu dipahami dan diproses sebagai pengetahuan dan teknologi baru yang akan menstimulasi perekonomian (Benhabib and Spiegel, 1994). Sudah menjadi hal yang pasti bahwa pendidikan merupakan salah satu instrumen utama yang menentukan kemajuan suatu bangsa, termasuk di Indonesia.

Pendidikan menjadi determinan yang penting bagi potensi pertumbuhan ekonomi Indonesia pada jangka panjang, mengingat produktivitas tenaga kerja Indonesia yang masih rendah karena rendahnya kualitas modal manusianya. Data Human Capital Index 2018 dari World Bank 2018 yang merupakan pengukuran kontribusi pendidikan dan kesehatan bagi produktivitas tenaga kerja menunjukan posisi Indonesia dengan nilai 0,53 berada dibawah peers country di ASEAN, yaitu Vietnam $(0,67)$, Malaysia $(0,62)$, serta Filipina $(0,55)$. Masalah pendidikan ini juga mempengaruhi kualitas hidup di Indonesia karena penduduk yang memiliki tingkat pendidikan yang lebih tinggi cenderung memiliki umur yang lebih panjang (life expectancy).

Pentingnya tingkat pendidikan masyarakat Indonesia bagi economic sustainability mendorong Pemerintah Indonesia melalukan reformasi kebijakan dalam bidang pendidikan sejak era reformasi dimulai. Reformasi ini didasarkan pada evaluasi kebijakan pendidikan pada era sebelum reformasi, yaitu kegagalan memberikan pendidikan dasar secara merata bagi anak usia sekolah dan keterbatasan proporsi anggaran pendidikan dalam APBN. Padahal, Pendidikan mutlak dibutuhkan untuk meningkatkan kualitas sumber daya manusia dan diharapkan akan mampu memberikan multiplier effect terhadap pembangunan negara pada umumnya dan pertumbuhan ekonomi pada khususnya. Selain karena desakan kebutuhan, pentingnya mendorong pendidikan yang berkualitas juga merupakan amanat konstitusi Undang-Undang Dasar 1945 yang merupakan cita-cita luhur Bangsa Indonesia. Konstitusi tersebut menjamin pendidikan bagi warga negaranya seperti yang tercantum dalam UUD 45 pasal 31 ayat (1) yang berbunyi "Setiap warga negara berhak mendapat pendidikan". Pasal 31 ayat (2) juga secara tegas menyatakan bahwa "Setiap warga negara wajib mengikuti pendidikan dasar dan pemerintah wajib membiayainya". Amanat UUD 1945 tersebut membuat Pemerintah Indonesia berkewajiban untuk memenuhi hak warga negaranya dalam mengakses pendidikan. UUD 1945 (yang telah diamandemen pada tahun 2002) juga mengamanatkan besaran anggaran pendidikan 20 persen dari postur APBD dan APBN (mandatory spending) yang tertuang di Undang-Undang Dasar1945 pasal 31 ayat 4".

Untuk memperkuat peran tersebut, Pemerintah Indonesia mempertajam dasar hukum kebijakan pendidikan Indonesia melalui Undang Undang No.20 tahun 2003 tentang Sistem Pendidikan Nasional (Sisdiknas). Undang-undang tersebut menjadi tonggak reformasi pendidikan di Indonesia dengan menegaskan tugas pemerintah dalam UUD 1945. UU Sisdiknas pasal 5 ayat (1) menyatakan bahwa "Setiap warga negara mempunyai hak yang sama untuk memperoleh pendidikan yang bermutu", bahkan pada pasal 6 ayat (1) dinyatakan bahwa "Setiap warga negara yang berusia tujuh tahun sampai lima belas tahun wajib mengikuti pendidikan dasar." Undangundang inipun menjadi landasan utama bagi kebijakan Wajib Belajar Sembilan Tahun atau pada tingkat minimal SMP.

Dalam mewujudkan program Wajib Belajar Sembilan Tahun, masalah biaya pendidikan merupakan hal prioritas. Biaya pendidikan inilah yang menjadi hambatan bagi masyarakat untuk mengakses pendidikan, sehingga pendidikan dikategorikan sebagai barang yang hanya dinikmati oleh orang yang mampu saja. Masalah pokok dalam pembiayaan pendidikan ini mencakup kebutuhan investasi, operasional, dan personalia sekolah. Tentu tidak semua masyakat dapat mendanai kebutuhan pembiayaan pendidikan tersebut, terlebih lagi masih banyak masyarakat Indonesia yang tidak mampu sehingga membutuhkan kebijakan afirmatif. Upaya Pemerintah Indonesia dalam mewujudkan program Wajib Belajar Sembilan Tahun adalah memberikan Dana Bantuan Operasional Sekolah (BOS) kepada sekolah-sekolah yang terdaftar. Sasaran dari program ini adalah seluruh peserta didik pada tingkat pendidikan dasar (SD dan SMP) serta satuan pendidikan lain yang sederajat.

BOS merupakan program pemerintah pusat untuk mengurangi kebutuhan biaya operasional 
nonpersonalia sekolah. Program ini secara tidak langsung akan membebasbiayakan seluruh siswa SD dan SMP terhadap biaya operasional sekolah, sehingga pada akhirnya akan meningkatkan enrollment ratio pada kedua jenjang tersebut. Pada intinya, program ini memiliki tujuan utama dalam mensukseskan program Wajib Belajar Sembilan Tahun secara merata dan meringankan beban keluarga dalam aspek pendidikan, setidaknya untuk tingkat SD dan SMP, sehingga dapat dilakukan realokasi untuk kegiatan produktif lainnya.

Sejak dilaksanakan pada Juli 2005, program BOS telah mampu meningkatkan enrollment ratio di Indonesia, gross enrollment ratio (Angka Partisipasi Kasar/APK ${ }^{1}$ ) maupun net enrollment ratio (Angka Partisipasi Murni/APM ${ }^{2}$ ) pada jenjang SD dan SMP. Hal ini dapat dilihat dari gambar berikut:

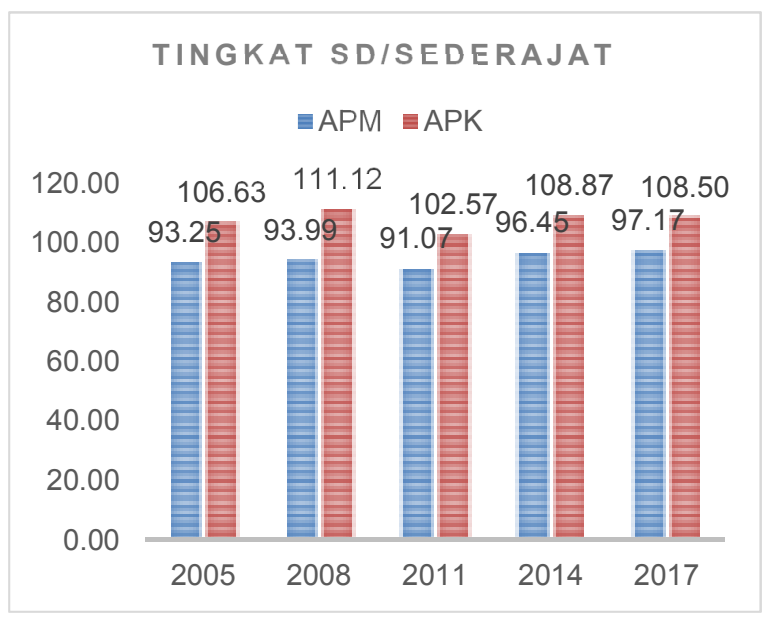

Gambar 1 APM dan APK pada Tingkat Pendidikan SD/Sederajat

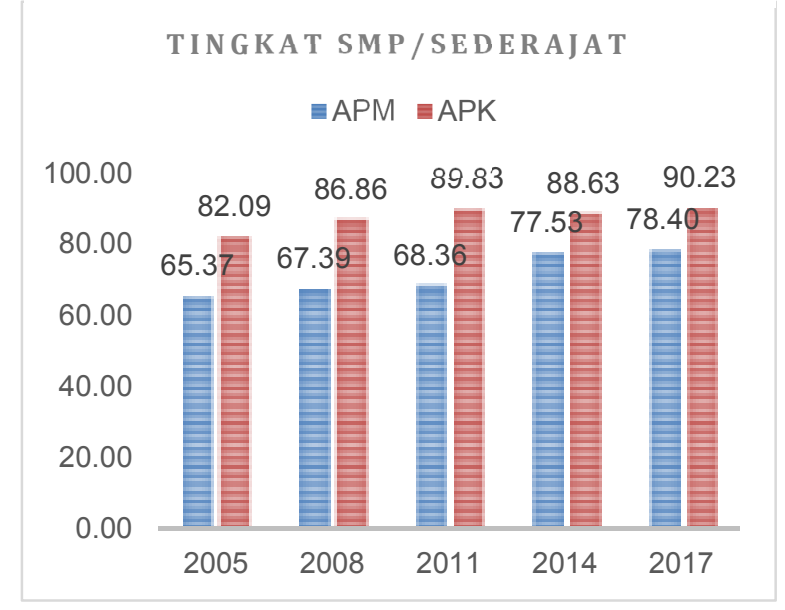

${ }^{1} \mathrm{APK}$ adalah proporsi anak sekolah pada suatu jenjang tertentu terhadap penduduk pada kelompok usia tertentu.

${ }^{2} \mathrm{APM}$ adalah proporsi penduduk pada kelompok umur jenjang pendidikan tertentu yang masih bersekolah terhadap penduduk pada kelompok umur tersebut.

\section{Gambar 2 APM dan APK pada Tingkat Pendidikan SMP/Sederajat}

Sumber: Badan Pusat Statistik

Pada tingkat SD, peningkatan secara signifikan terjadi pada APM bahkan sudah hampir mendekati angka 100. Sedangkan pada tingkat SMP, terlihat kenaikan APM dan APK dari tahun 2005 sampai 2017. Walaupun terjadi kenaikan, besaran dana BOS yang dikucurkan pemerintah pusat melalui Dana Alokasi Khusus Non-Fisik dan semakin progresifnya alokasi dana tersebut, pencapaian ini masih belum menunjukan kesuksesan Program Wajib Belajar 9 Tahun karena masih ada calon peserta didik yang tidak mengikuti pendidikan, khususnya pada tingkat SMP. Berbagai lembaga risetpun juga mengkonfirmasi bahwa alokasi dana BOS memang dapat meningkatkan enrollment ratio di Indonesia, namun tetap masih menyisakan masalah pendidikan. World Bank (2015) menemukan bahwa angka transisi (siswa yang lanjut ke tingkat pendidikan selanjutnya) tidak menunjukan lonjakan yang sama dengan angka partisipasi sejak BOS diperkenalkan. Laporan World Bank yang mengevaluasi dana BOS selama satu dekade ini juga menemukan bahwa dana BOS hanya memiliki pengaruh yang bersifat sementara dan cenderung kecil terhadap biaya yang menjadi beban rumah tangga, khususnya pada rumah tangga miskin. Laporan ini juga menemukan partisipasi di tingkat SD dan SMP tinggi dan terus meningkat serta perlunya fokus yang lebih besar pada peningkatan mutu sebagai tujuan program BOS.

Pemerintah Indonesia memang sudah melakukan reorientasi tujuan pemberian dana BOS yang pada awalnya untuk meningkatkan enrollment ratio, namun juga untuk perluasan akses menuju peningkatan kualitas walaupun masih sebagai tujuan kedua. Kualitas pendidikan Indonesia bahkan juga tertinggal jika dibandingkan peers country, seperti Vietnam. Indikator ini dapat dilihat dari Programme for International Student Assessment (PISA) 2015 (OECD, 2017) yang melakukan benchmark mutu pendidikan Indonesia secara internasional. Laporan PISA tersebut menunjukan kualitas pendidikan di Indonesia masih berada di peringkat ke-65 dari 69 negara yang disurvei. Hal ini jauh dibandingkan dengan Vietnam yang berada di peringkat delapan. Padahal, secara alokasi anggaran, Vietnam juga mengalokasikan 20\% APBNnya untuk sektor pendidikan.

Isu lain mengenai pendidikan Indonesia adalah tidak meratanya akses pendidikan di Indonesia. Hal ini terlihat dari data cakupan sekolah (1 sekolah mencakup beberapa luas area) yang memperlihat gap yang cukup besar atar 
daerah di Indonesia, khususnya di Provinsi Papua. Hal ini mendorong adanya Provinsi yang memiliki APM jauh dibawah rata-rata tingkat nasional, seperti Provinsi Papua yang memiliki APM untuk SD 78,83 dan SMP 56,13 disaat pada tingkat nasional APM untuk SD berada pada angka 97,19 dan SMP 78,4 (tahun 2017). Kesenjangan ini pula yang membuat penyaluran dana BOS sebagai ujung tombak program Wajib Belajar Sembilan Tahun menggunakan mekanisme Dana Alokasi Khusus Nonfisik agar pengelolaannya lebih diatur pada tingkat daerah dan sesuai dengan kebutuhan. Sebagai informasi, besaran dana BOS yang diterima siswa di seluruh provinsi memiliki nilai nominal yang sama berdasarkan satuan biaya yang ditetapkan oleh Kementerian Pendidikan dan Kebudayaan.

Penggunaan dana BOS pada tingkat provinsi tentu memiliki variasi output yang bermacammacam sehingga mendorong pula variasi efisiensi yang bermacam-macam pula. Hal yang menarik untuk ditelaah lebih lanjut adalah faktor-faktor yang mempengaruhi efisiensi tersebut. Menurut Afonso et al. (2003), efisiensi anggaran publik dalam bidang pendidikan tidak hanya dipengaruhi oleh opportunity indicators yang berasal dari aspek pendidikan saja, namun juga ada faktor yang berasal dari performa dan stabilitas ekonomi.

Masalah serta faktor yang mempengaruhi efisiensi penggunaan dana BOS tersebut yang mendorong peneliti untuk melakukan penelitian ini. Dengan menggunakan data panel 33 provinsi di Indonesia pada periode 2014 sampai 2017, peneliti mencoba melihat lebih dalam pada tingkat provinsi mengenai efisiensi penggunaan dana BOS dan halhal yang mempengaruhinya, mulai dari indikator yang berasal dari aspek pendidikan sampai dengan indikator peforma ekonomi setiap provinsi. Hal ini sangat penting bagi pemangku kebijakan untuk memberikan gambaran mengenai faktor-faktor yang mempengaruhi efisiensi dan menjadi masukan bagi mereka untuk membuat regulasi yang berlandaskan riset, mengingat program Wajib Belajar Sembilan Tahun merupakan amanat undang-undang. Peneliti menggunakan metode Data Envelopment Analysis (DEA) dengan output untuk anggaran BOS adalah Angka Partisipasi Murni (APM), nilai Ujian Nasional, angka putus sekolah, angka transisi ke jenjang berikutnya, dan persentase ruang kelas dengan kondisi baik.

Untuk melihat faktor -faktor yang mempengaruhi efisiensi tersebut, peneliti menggunakan Tobit Estimation Technique dengan variabel pertumbuhan PDRB, kualitas guru, tingkat kemiskinan, Indeks Pembangunan Manusia (IPM), dan cakupan sekolah sebagai determinan. Novelty dalam penelitian ini adalah belum adanya penelitian yang melakukan studi efisiensi penggunaan dana BOS di Indonesia beserta faktorfaktor yang mempengaruhinya, sehingga penelitian ini akan memberikan saran yang genuine bagi pemangku kebijakan sektor pendidikan pada pemerintahan pusat maupun daerah.

Bagian-bagian selanjutnya menjelaskan halhal sebagai berikut. Bagian dua membahas studi literatur yang relevan. Bagian ketiga menguraikan data dan metodologi penelitian. Bagian empat menyajikan dan membahas hasil penelitian. Bagian lima berupa kesimpulan dan saran. Bagian terakhir merupakan implikasi dan keterbatasan penelitian sebagai masukan bagi penelitian-penelitian selanjutnya.

\section{KERANGKA TEORI DAN PENGEMBANGAN HIPOTESIS}

\subsection{Sektor Pendidikan Dalam Pengeluaran Publik}

Pendidikan merupakan salah satu komponen penting di dalam pembangunan. Mereka yang memiliki tingkat pendidikan yang lebih tinggi, memiliki kesempatan yang lebih besar untuk memperbaiki keadaan ekonomi atau kesejahteraan mereka beserta dengan keluarga dan keturunannya. Pendidikan yang tinggi dapat menjadi salah satu sinyal utama yang mengindikasikan tingkat produktivitas seseorang sehingga orang tersebut dapat memperoleh pekerjaan yang layak. Namun sayangnya, tingkat pendidikan masyarakat di negara-negara berkembang, termasuk Indonesia, belum merata. Kesenjangan tersebut dapat terlihat dengan jelas apabila membandingkan tingkat pendidikan masyarakat suatu daerah dengan aktivitas ekonomi di suatu daerah pada Gambar 3 yang menunjukan korelasi positif antara enrollment ratio (APM) dengan PDRB Nominal pada 33 provinsi di Indonesia tahun 2014 sampai dengan 2017.

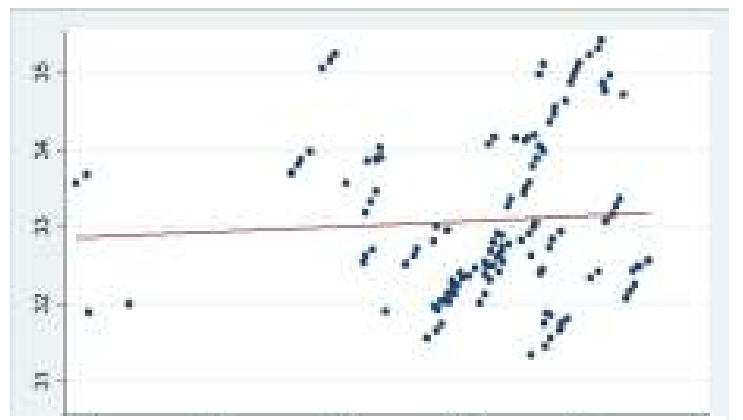

Gambar 3 Hubungan Antara PDRB Nominal dan APM

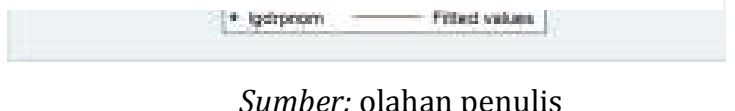

Teori Becker (1975) telah menjelaskan secara rinci dampak dari investasi pada modal manusia, baik dari segi sekolah maupun pelatihan di tingkat perusahaan. Becker menjelaskan bahwa pengaruh 
dari tingkat pendidikan terhadap pendapatan akan berbeda-beda pada setiap individu bergantung dari umur ketika seseorang mendapatkan pendidikan ataupun pelatihan. Dampak dari pendidikan atau pelatihan tersebut akan semakin tinggi pada jangka panjang apabila umur seseorang ketika mendapatkan pendidikan tersebut semakin muda. Oleh karena itu, penting bagi seseorang untuk mendapatkan pendidikan pada usia dini atau dengan mengikuti program Wajib Belajar Sembilan Tahun.

Penelitian Becker tersebut sangat spesifik pada tingkat mikro, namun pada tingkat makro Psacharopoulos (1985) menyatakan bahwa pengeluaran untuk pendidikan bukanlah sebuah konsumsi semata, melainkan sebuah investasi modal manusia. Investasi di bidang modal manusia ini merupakan hal yang penting, terutama bagi negara berkembang, karena investasi tersebut dapat meningkatkan kapasitas produksi dan meningkatkan tingkat profitabilitas dari investasi lainya seperti investasi barang modal. Semakin tinggi rata-rata tingkat pendidikan pekerja di suatu negara, maka semakin tinggi kemampuan negara tersebut untuk mendapatkan imbal hasil dari investasi baik pada barang modal maupun infrastruktur. Hal tersebut dikarenakan kemampuan manusia, sebagai pengguna dari barang-barang fisik tersebut, dalam beradaptasi terhadap perkembangan teknologi semakin baik. Psacharopoulos menemukan bahwa hasil investasi di bidang pendidikan (modal manusia) pada abad $\mathrm{XX}$, lebih memiliki pengaruh di daerah Afrika dibandingkan dengan daerah-daerah lain seperti Eropa atau Amerika Latin. Hal tersebut dikarenakan tingkat pendidikan di Afrika relatif lebih rendah dibandingkan dengan negara lain sehingga tambahan investasi di bidang pendidikan membuahkan hasil yang lebih tinggi. Hal tersebut sesuai dengan konsep umum marginal return to scale di mana pada kasus ini adalah peningkatan investasi terhadap pertumbuhan ekonomi.

Psacharopoulos menambahkan bahwa tingkat keberhasilan investasi pendidikan dipengaruhi oleh efisiensi eksternal dan efisiensi internal. Efisiensi eksternal (Psacharopoulos, 1981) diakibatkan oleh tiga hal yaitu: 1) Tingkat pendidikan pada saat investasi dilakukan; 2) Jenjang pendidikan dasar memberikan dampak yang lebih signifikan dibandingkan dengan pendidikan yang lebih spesifik (berlaku untuk di negara berkembang); 3) Keuntungan investasi pendidikan sangatlah tinggi sehingga menguntungkan bagi siapa saja yang melakukannya. Sementara itu, efisiensi internal lebih ditekankan pada tingkat mikro seperti kualitas guru, sarana dan prasarana sekolah, dan buku yang digunakan dalam menghasilkan murid yang berkualitas. Namun permasalahan yang sering muncul di negara berkembang, termasuk Indonesia, adalah kesenjangan tingkat pendidikan baik dari segi jumlah sekolah maupun kualitasnya. Kesenjangan tingkat pendidikan itu pun tidak terlepas dari kurangnya pembangunan dan pertumbuhan ekonomi yang merata sehingga pemerintah di tingkat daerah tidak mampu membantu secara signifikan dalam meningkatkan kualitas dan kuantitas pendidikan.

Banyak hal yang telah dilakukan oleh pemerintah pusat untuk mengatasi permasalahan pendidikan yang tidak merata ini, salah satunya adalah dengan membuat pengeluaran pemerintah pusat untuk sektor pendidikan bersifat mandatory spending. Namun, pertanyaan lain muncul seberapa efisien pengeluaran pemerintah tersebut dalam mengatasi permasalahan pendidikan di negara berkembang? Berbagai literatur telah membahas mengenai efisiensi pengeluaran pemerintah dan dampaknya terhadap tingkat pendidikan seperti Fonchamnyo dan Sama (2014) dan Gavurova, et al. (2017), namun sebelum membahas lebih lanjut, perlu didalami mengenai apa itu pengeluaran pemerintah yang efisien.

Efisiensi merupakan perbandingan antaran tingkat keluaran yang dihasilkan (outcome) dan jumlah sumber daya yang digunakan (resource). Sementara pengeluaran pemerintah adalah besaran anggaran yang dikeluarkan oleh pemerintah dengan tujuan stabilisasi, alokasi, dan distribusi. Oleh karena itu, efisiensi pengeluaran pemerintah adalah perbandingan antara hasil, yang menjadi tujuan pemerintah, dan anggaran yang dikeluarkan oleh pemerintah. Tingkat efisiensi pengeluaran pemerintah sangat dipengaruhi oleh keadaan pasar, institusi, dan bagaimana dana tersebut digunakan (Afonso et al., 2005). Keadaan pasar adalah bagaimana respon pasar terhadap pengeluaran pemerintah. Hal tersebut dipengaruhi oleh beberapa indikator seperti kualitas pendidikan masyarakat, tingkat kesehatan, stabilitas dan performa ekonomi. Semakin baik keadaan pasar akan membuat semakin efisien pengeluaran pemerinah karena tingkat respon pasar yang relatif lebih cepat dibandingkan dengan daerah yang memiliki keadaan pasar lebih buruk. Sementara keadaan institusi memiliki keterkaitan yang erat dengan bagaimana dana tersebut digunakan, terutama dengan hal-hal yang bersifat administratif dan teknis seperti kualitas pelaksanaan, ketepatan kebijakan, korupsi, dan kualitas sosialisasi yang dilakukan. Afonso et al. (2008) menemukan bahwa distribusi pendapatan berpengaruh dan tingkat pendidikan merupakan hal yang paling signifikan dalam mempengaruhi tingat efisiensi pengeluaran pemerintah, sementara keadaan institusi memberikan hasil yang sesuai namun efek tersebut cenderung sangat dipengaruhi oleh distribusi pendapatan. 
Meskipun tingkat efisiensi pengeluaran pemerintah dipengaruhi oleh tingkat pendidikan dan kesehatan, Gupta dan Verhoeven (2001) menemukan hasil yang berkebalikan, bahwa tingkat pendidikan dan kesehatan dipengaruhi oleh tingkat efisiensi pengeluaran pemerintah. Pada penelitiannya, Gupta dan Verhoeven menemukan bahwa besaran pengeluaran pemerintah di sektor pendidikan dan kesehatan tidak serta merta meningkatkan kualitas dan kuantitas tingkat pendidikan di Afrika, hal tersebut disebabkan oleh rendahnya efisiensi pengeluaran pemerintah di sektor tersebut dibandingkan dengan pengeluaran pemerintah di negara-negara Asia. Hal tersebut menyebabkan tidak berlakunya marginal return to scale mengingat tingkat pendidikan di Afrika relatif lebih rendah dibandingkan dengan negara-negara di Asia. Fonchamnyo dan Sama (2014) melakukan penelitian serupa di Kamerun, Republik Chad, dan Afrika Tengah. Hasilnya adalah pengeluaran pemerintah Republik Chad lebih besar dibandingkan dengan Afrika Tengah dan Kamerun, namun juga merupakan negara yang paling tidak efisien dalam pengeluaran di sektor pendidikan dan kesehatan. Kualitas penganggaran dan manajemen keuangan merupakan salah satu faktor penting dalam meningkatkan efisiensi, sementara korupsi berpengaruh secara negatif.

\subsection{Sekilas Mengenai Dana BOS}

Mengacu pada Buku Petunjuk Teknis Bantuan Operasional Sekolah (BOS) yang dikeluarkan Kementerian Pendidikan dan Kebudayaan setiap tahunnya (peneliti mengacu pada Petunjuk Teknis Tahun 2017), alokasi dana BOS sejatinya merupakan program Pemerintah Pusat untuk penyediaan pendanaan biaya operasi non personalia bagi satuan pendidikan dasar dan menengah. Tujuan penggunaan dana BOS ini dibagi beradasarkan jenjangnya, yaitu tujuan untuk tingkat SD dan SMP atau sederajat dan tujuan tingkat SMA atau sederajat. Khusus untuk tingkat SD dan SMP atau sederajat, BOS memiliki tujuan:

1) membantu penyediaan pendanaan biaya operasi non personil sekolah, akan tetapi masih ada beberapa pembiayaan personil yang masih dapat dibayarkan dari dana BOS;

2) membebaskan pungutan biaya operasi sekolah bagi peserta didik SD/SDLB/SMP/SMPLB yang diselenggarakan oleh Pemerintah Pusat atau pemerintah daerah;

3) meringankan beban biaya operasi sekolah bagi peserta didik SD/SDLB/SMP/SMPLB yang diselenggarakan oleh masyarakat; dan/atau

4) membebaskan pungutan peserta didik yang orangtua/walinya tidak mampu pada SD/SDLB/SMP/SMPLB yang diselenggarakan oleh masyarakat.
Dana BOS ditujukan untuk sekolah negeri dan swasta yang sudah terdata dalam sistem Data Pokok Pendidikan Dasar dan Menengah (Dapodikdasmen) dan sudah memiliki izin operasional. Penyaluran dana juga dilakukan dalam periode tertentu, yaitu setiap periode tiga bulanan, yaitu periode Januari-Maret, April-Juni, Juli-September dan Oktober-Desember. Besaran dana BOS yang diterima oleh sekolah dihitung berdasarkan jumlah siswa yang ada di sekolah. Data jumlah siswa yang digunakan dalam perhitungan besar dana BOS bagi sekolah adalah data dari Dapodikdasmen dengan kriteria tertentu.

Adapun satuan biaya untuk perhitungan besar dana BOS yang diberikan ke sekolah adalah untuk tahun 2017:

1) Jenjang SD: Rp 800.000,-/siswa/tahun

2) Jenjang SMP: Rp 1.000.000,-/siswa/tahun

Penggunaan dana BOS juga sangat rigid diatur dalam Juknis yang memiliki kekuatan hukum dalam bentuk Peraturan Menteri Pendidikan dan Kebudayaan. Penggunaan dana BOS tersebut tidak langsung diberikan kepada setiap siswanya, namun dikelola oleh setiap sekolah. Pemerintah menerapkan Manajemen Berbasis Sekolah (MBS), yang memberikan kebebasan dalam perencanaan, pengelolaan, dan pengawasan program yang disesuaikan dengan kondisi dan kebutuhan sekolah. Adapun aturan penggunaannya hanya boleh dialokasikan untuk hal-hal berikut:

1) Pengembangan Perpustakaan yang mencakup segala kebutuhan peserta didik perihal perbukuan;

2) Penerimaan Peserta Didik Baru;

3) Kegiatan Pembelajaran dan Ekstrakurikuler;

4) Kegiatan Evaluasi Pembelajaran dan Ekstrakurikuler;

5) Pengelolaan Sekolah, termasuk operasional sekolah untuk pembelajaran;

6) Pengembangan Profesi Guru dan Tenaga Kependidikan, serta Pengembangan Manajemen Sekolah;

7) Langganan Daya dan Jasa;

8) Pemeliharaan Sarana dan Prasarana Sekolah;

9) Pembayaran Honor, termasuk Guru honorer dan tenaga perbantukan lainnya;

10) Pembelian/Perawatan Alat Multi Media Pembelajaran;

11) Biaya Lainnya yang diatur dalam petunjuk teknis.

Penelitian terdahulu yang melakukan analisis efektivitas dana BOS pada tingkat nasional dengan uji statistik dilakukan oleh Aziz (2009). Penelitian ini melakukan uji paired sample $t$ test terhadap setiap outcome yang diharapkan dari program BOS ini yang terdiri dari varibel APK, APM, Siswa Mendaftar, Putus Sekolah, Lulus Sekolah dan Lanjut Sekolah di tingkat SD dan SMP pada periode 2005 sampai 2008. Penelitian tersebut menemukan program BOS belum dianggap efektif 
memperbaiki variabel-variabel outcome tersebut. Penelitian lainnya yang berfokus pada program wajib belajar dilakukan oleh Rosser dan Joshi (2013). Penelitian ini menemukan bahwa kebijakan wajib belajar masih belum dapat meningkatkan akses dan kualitas pendidikan karena adanya biaya ilegal dari oknum di sektor pendidikan. Alasannya adalah hilangnya kualitas karena kepadatan peserta didik yang berlebihan dan tingkat drop-out yang tinggi.

\section{METODE PENELITIAN}

Penelitian ini bertujuan untuk menganalisis efisiensi dana BOS pada tingkat SD dan SMP di setiap provinsi dan mengidentifikasi determinan tingkat efisiensi tersebut. Unit analisis dalam penelitian ini adalah 33 provinsi di Indonesia pada rentang waktu 2014 sampai dengan 2017 dengan melaksanakan perhitungan sebanyak dua kali, yaitu pada tingkat SD dan SMP. Adapun provinsi yang tidak dimasukkan ke dalam penelitian ini adalah Provinsi Kalimantan Utara karena provinsi tersebut baru terbentuk pada tahun 2013 dan ketersedian datanya masih belum lengkap. Penelitian ini menggunakan data sekunder yang diperoleh dari Statistik Sekolah Menengah Pertama dan Statistik Sekolah Dasar publikasi Kementerian Pendidikan dan Kebudayaan Republik Indonesia serta data Badan Pusat Statistik (BPS) untuk variabel-variabel daerah selain data pendidikan. Untuk dana BOS, peneliti mendapatkan data dari laman Kementerian Pendidikan dan Kebudayaan.

Penelitian ini menggunakan dua pendekatan kuantitatif yaitu Data Envelopment Analysis (DEA) dan metode regresi data panel estimasi Tobit. Tahap pertama pada penelitian ini adalah mendapatkan nilai efisiensi penggunaan dana BOS terhadap partisipasi murni sekolah di setiap provinsi dengan menggunakan metode DEA pada setiap tahunnya. Setelah mendapatkan nilai efisiensi tersebut, berikutnya penelitian ini akan menganalisis faktor-faktor apa yang mempengaruhi tingkat efisiensi dengan menggunakan metode estimasi tobit.

\subsection{Data Envelopment Analysis (DEA)}

DEA merupakan metode matematik, nonparametrik yang umum digunakan untuk menganalisa tingkat efisiensi relatif berdasarkan sampel decision making unit (DMU) atau suatu unit produksi ${ }^{3}$, dalam hal ini adalah provinsi. Perlu diperhatikan bahwa metode DEA mengasumsikan seluruh DMU bersifat homogen, implikasinya adalah dampak dari dana BOS menjadi overestimate karena tidak memperhitungkan dana pendidikan lainnya yang mungkin dianggarkan

3 Casu B. dan Molyneux P, A Comparative Study in European Banking (Applied Economics, 2003) hlm. 17 oleh pemerintah daerah. Penelitian ini menggunakan metode DEA karena memungkinkan penulis untuk memperhitungkan tingkat efisiensi dari dana BOS sebagai input terhadap beberapa variabel output ${ }^{4}$. Adapun variabel input yang digunakan adalah persentase dana BOS terhadap produk domestik regional bruto (PDRB) provinsi. Peneliti mengubah bentuk dana BOS menjadi persentase terhadap PDRB untuk mempermudah perhitungan dan menyesuaikan dana BOS berdasarkan kemampuan ekonomi yang terjadi di daerah tersebut dan dapat lebih dibandingkan antar provinsi.

Tujuan utama dana BOS adalah untuk meningkatkan angka partisipasi sekolah di setiap daerah, namun sejak tahun 2009 pemerintah menambahkan tujuan lain berupa peningkatan kualitas pendidikan. Oleh karena itu, variabel output yang digunakan dalam perhitungan DEA adalah merupakan variasi dari indikator yang mengukur kuantitas dan kualitas pendidikan, yaitu: 1) angka partisipasi murni (APM) baik di tingkat SD maupun SMP; 2) tingkat putus sekolah; 3) ratarata nilai ujian nasional (UN); 4) angka melanjutkan sekolah ke jenjang selanjutnya atau angka transisi.

Peneliti memilih angka partisipasi sekolah murni dibandingkan dengan angka partisipasi kasar sebagai tujuan kuantitas dana BOS karena angka partisipasi murni merupakan persentase siswa yang bersekolah pada jenjang usia terkait terhadap jumlah penduduk dengan usia yang sama. Hal tersebut membuat APM lebih representatif dalam menjelaskan partisipasi sekolah pada usia yang seharusnya. Selain itu, tujuan kuantitas dari adanya dana BOS dalam penelitian ini adalah rendahnya tingkat putus sekolah. Dengan adanya bantuan dana untuk siswa yang bersekolah diharapkan mereka mampu untuk terus melanjutkan tingkat pendidikan karena mengurangnya beban biaya pendidikan.

Selanjutnya, angka melanjutkan sekolah dan rata-rata ujian nasional merupakan tujuan peningkatan kualitas pendidikan dari dana BOS. Angka melanjutkan sekolah merupakan persentase siswa yang melanjutkan pendidikan berikutnya terhadap jumlah siswa yang lulus jenjang tertentu pada tahun yang sama. Studi oleh Wolrd Bank (2015) juga menggunakan indikator ini untuk melihat kinerja dana BOS. Ada hal yang perlu menjadi perhatian ketika menggunakan variabel ini, yaitu variabel ini menggunakan jumlah siswa yang melanjutkan ke jenjang berikutnya tanpa memperhatikan asal sekolah sebelumnya sehingga

\footnotetext{
${ }^{4}$ Fonchamnyo, D.C. dan Sama, M.C., Determinants of Public Spending Efficiency in Education and Health: Evidence from Selected CEMAC Countries (New York: Journal of Economics and Finance, 2016) hlm. 203
} 
angka melanjutkan tersebut tidak memperhitungkan faktor migrasi antardaerah untuk tujuan pendidikan. Sebagai contoh, seseorang yang lulus jenjang pendidikan sekolah dasar di Provinsi Jawa Barat dan melanjutkan ke jenjang pendidikan sekolah menengah pertama di DKI Jakarta akan masuk ke perhitungan angka melanjutkan sekolah di Provinsi Jakarta. Hal tersebut dapat menimbulkan bias pada peningkatan angka melanjutkan sekolah di Provinsi DKI Jakarta dan penurunan angka melanjutkan sekolah di Provinsi Jawa Barat.

Sementara rata-rata nilai ujian nasional merupakan angka rata-rata nilai ujian nasional bahasa indonesia, bahasa inggris, matematika, dan ilmu pengetahuan alam di masing-masing provinsi. Indikator ini penting untuk melihat mutu pendidikan setiap jenjangnya. Namun, penelitian ini menggunakan variabel rata-rata nilai UN hanya pada jenjang pendidikan SMP karena keterbatasan data yang dimiliki oleh Kementerian Pendidikan dan Budaya hanya menyimpan data nilai UN untuk jenjang pendidikan tersebut, sementara data nilai UN SD disimpan oleh masing-masing dinas pendidikan provinsi karena penyelenggaraan UN SD masih menjadi tanggung jawab pemerintah provinsi.

Tabel 1 Variabel perhitungan Data Envelopment Analysis

\begin{tabular}{|c|c|}
\hline Input & Output \\
\hline \multirow{5}{*}{$\begin{array}{l}\text { Persentase dana BOS jenjang } \\
\text { pendidikan tertentu di } \\
\text { provinsi tertentu terhadap } \\
\text { besaran PDRB provinsi } \\
\text { tersebut }\end{array}$} & $\begin{array}{l}\text { Angka partisipasi murni } \\
\text { jenjang pendidikan tertentu } \\
\text { di provinsi tertentu }\end{array}$ \\
\hline & $\begin{array}{l}\text { Persentase ruang sekolah } \\
\text { baik terhadap total ruang } \\
\text { sekolah }\end{array}$ \\
\hline & $\begin{array}{l}\text { Tingkat putus sekolah di } \\
\text { provinsi tertentu }\end{array}$ \\
\hline & $\begin{array}{l}\text { Rata-rata nilai UN di } \\
\text { provinsi tertentu* }\end{array}$ \\
\hline & $\begin{array}{l}\text { Angka melanjutkan sekolah } \\
\text { di provinsi tertentu }\end{array}$ \\
\hline
\end{tabular}

Catatan: rata-rata nilai UN hanya berlaku di dalam

perhitungan jenjang pendidikan SMP

Metode DEA pertama kali dikembangkan oleh Charnes, Cooper, dan Rhodes (1978). Mereka mengukur tingkat efisiensi dari unit produksi sebagai rasio maksimal dari output terbebankan terhadap input terbebankan di mana setiap unit produksi memiliki nilai antara nol sampai dengan satu. Perhitungan ini mengikuti asumsi constant return to scale (CRS) di mana tidak terdapat efek dari skala keekonomian. Tidak lama kemudian pada tahun 1984 Banker, Charnes, dan Cooper mengembangkan model variable return to scale (VRS) dari metode DEA. Kelebihan metode ini adalah asumsi bahwa setiap unit produksi berproduksi baik pada tingkat increasing return to scale atau decreasing return to scale. Perbedaan utama antara CRS dan VRS adalah CRS berlaku apabila setiap unit produksi beroperasi pada tingkat yang optimum, sementara VRS berlaku apabila setiap unit produksi belum atau telah melampau kapasitas optimumnya.

Berikut persamaan dari tingkat efisiensi menurut Charnes, Cooper, dan Rhodes (1978):

$$
\text { maksimum } h_{0}=\frac{\sum_{r=1}^{s} u_{r} y_{r 0}}{\sum_{i=1}^{m} v_{i} x_{i 0}}
$$

Terbatas pada:

$$
\begin{aligned}
& \frac{\sum_{r=1}^{s} u_{r} y_{r 0}}{\sum_{i=1}^{m} v_{i} x_{i j}} \leq 1 ; \quad j=1, \ldots, n . \\
& u_{r}, v_{i} \geq 0 ; \quad r=1, \ldots, s ; i=1, \ldots, m .
\end{aligned}
$$

Di mana $\mathrm{y}_{\mathrm{rj}}, \mathrm{x}_{\mathrm{ij}}$, adalah variabel input dan output dari unit produksi $\mathrm{j}$, dan $\mathrm{u}_{\mathrm{r}}, \mathrm{v}_{\mathrm{i}} \geq 0$ adalah variabel pembeban yang merupakan solusi dari persamaan. Hasil dari perhitungan tingkat efisiensi unit produksi j merupakan hasil perbandingan antar unit produksi dan diurutkan dari yang paling efisien (bernilai 1) ke yang tidak efisien (bernilai $\leq 1)$.

Metode ini menggunakan asumsi fungsi produksi yang konveks. Unit produksi yang memiliki tingkat efisiensi $\theta^{*}$ paling tinggi akan berada pada garis konveks, sementara itu semakin jauh titik unit produksi dari garis tersebut, menandakan bahwa unit produksi semakin tidak efisien. Sebagai contoh, pada Gambar 4 di bawah, unit produksi A, C, dan D merupakan unit produksi yang beroperasi secara efisien, sementara unit produksi B beroperasi secara tidak efisien.

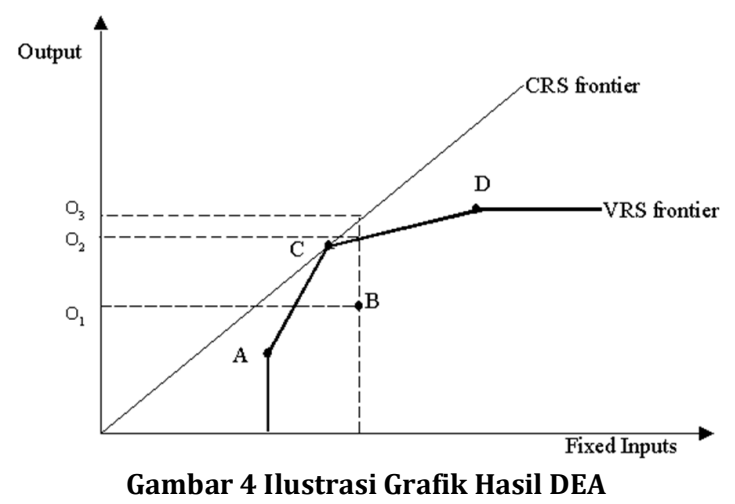

Sumber: FAO

(http://www.fao.org/docrep/006/y5027e/y5027e0e.htm)

Metode DEA yang beroperasi dengan asumsi VRS dapat dibagi menjadi dua kategori 
berdasarkan relasi antara input dan outputnya. Pertama, DEA berorientasi input merupakan model untuk mengidentifikasi apakah suatu unit produksi dapat mempertahankan tingkat outputnya apabila tingkat inputnya dikurangi seminim mungkin. Sementara yang kedua, DEA berorientasi output merupakan model untuk mengidentifikasi apakah suatu unit produksi dapat meningkatkan tingkat outputnya semaksimal mungkin dengan tingkat input yang ada.

Berdasarkan pemaparan di atas, metode DEA yang akan digunakan pada penelitian kali ini adalah DEA VRS berorientasi output. Metode tersebut dipilih karena pengeluaran pemerintah, termasuk pengeluaran pendidikan, sejatinya harus digunakan secara optimal untuk mendorong pencapaian target pemerintah. Selain itu, pemerintah secara tegas menetapkan batas minimum anggaran pendidikan sebesar $20 \%$ dari APBN yang berarti terdapat keseriusan pemerintah untuk mendorong kualitas pendidikan di Indonesia. Dengan tren anggaran pemerintah yang terus meningkat, kecil kemungkinan bahwa dana BOS yang dikirimkan ke daerah pada tahun-tahun berikutnya akan berkurang.

\subsection{Metode Estimasi Data Panel Tobit}

Metode estimasi data panel tobit merupakan metode estimasi data panel yang digunakan untuk mengestimasi data yang memiliki nilai batas atas atau batas bawah. Penelitian ini menggunakan model estimasi panel data tobit karena menggunakan efisiensi hasil dari perhitungan model DEA sebagai variabel terikat yang memiliki rentang nilai nol sampai dengan satu.

Pada model estimasi data panel tobit, penelitian ini menggunakan variabel sosioekonomi untuk mengestimasi faktor yang mempengaruhi tingkat efisiensi suatu daerah, adapun variabel tersebut adalah sebagai berikut:

Tabel 2 Variabel input dan output metode perhitungan Data Envelopment Analysis

\begin{tabular}{lll}
\hline \multicolumn{1}{c}{ Variabel } & \multicolumn{1}{c}{ Deskripsi } & Hipotesis \\
\hline $\begin{array}{l}\text { Efisiensi teknis unit } \\
\text { produksi (Eff) }\end{array}$ & Hasil estimasi DEA & $\begin{array}{l}\text { Variabel } \\
\text { terikat }\end{array}$ \\
$\begin{array}{l}\text { Pertumbuhan ekonomi } \\
(\text { Gpdrb) }\end{array}$ & $\begin{array}{l}\text { Pertumbuhan y-o-y } \\
\text { pdrb provinsi }\end{array}$ & positif \\
$\begin{array}{l}\text { Kualitas guru (Layak) } \\
\text { Persentase guru dan } \\
\text { kepala sekolah layak } \\
\text { (memiliki jenjang } \\
\text { pendidikan di atas S1) }\end{array}$ & Positif \\
$\begin{array}{l}\text { Indeks pembangunan } \\
\text { manusia (Ipm) }\end{array}$ & $\begin{array}{l}\text { Indeks pembangunan } \\
\text { manusia }\end{array}$ & Positif \\
$\begin{array}{l}\text { Tingkat kemiskinan } \\
\text { (Miskin) }\end{array}$ & headcount index & negatif
\end{tabular}

Akses ke jenjang pendidikan (Infra) Luas wilayah provinsi per jumlah sekolah

negatif

Variabel dummy pulau (Dumpulau)

jawa sebagai basis (0) negatif

$$
\begin{aligned}
& E f f_{i}=G p d r b_{i}+T p t_{i}+\text { Layak }_{i}+\text { Miskin }_{i} \\
& + \text { Akses }_{i}+\text { Dumpulau }_{i}+\varepsilon_{i}
\end{aligned}
$$

Variabel penjelas pertama adalah performa ekonomi daerah berdasarkan studi Afonso et al (2005). Dalam studi tersebut, indikator ini disebut sebagai standard "Musgravian" indicators. Variabel ini adalah pertumbuhan ekonomi $G p d r b_{i}$. Variabel ini merupakan performa ekonomi fungsi efisiensi alokatif dari pengeluaran pemerintah ${ }^{5}$. Performa ekonomi yang semakin tinggi biasanya ditandai dengan kesejahteraan masyarakat yang meningkat akibat dari peningkatan permintaan terhadap suatu barang dan/atau jasa. Untuk memenuhi peningkatan permintaan barang dan/atau jasa tersebut, produsen membutuhkan tambahan input produksi, diantaranya adalah pekerja dan produktivitas pekerja. Sehingga performa ekonomi meningkat ketika suatu provinsi memiliki pertumbuhan ekonomi yang lebih tinggi.

Kualitas guru Layak merupakan rasio guru yang memiliki tingkat pendidikan sarjana terhadap total guru di provinsi tertentu. Tingkat pendidikan guru merupakan proxy dari kualitas tenaga pendidik di provinsi tertentu. Tingginya kualitas tenaga pendidik diharapkan dapat meningkatkan efisiensi dana BOS baik dari sisi pengelolaan dana maupun output per guru. Kementerian Pendidikan dan Kebudayaan mengkategorikan guru layak sebagai kepala sekolah atau guru yang berijazah S1 / D4 dan yang lebih tinggi. Indikasi yang dapat dilihat dari variabel ini adalah ketika dana BOS dikelola oleh sumber daya manusia yang layak secara pendidikan, dalam hal ini kepala sekolah dan guru, maka penggunaan dana BOS akan lebih efisien dalam mencapai outputnya.

Indeks pembangunan manusia $\mathrm{Ipm}_{i}$ merupakan angka tingkat kualitas sumber daya manusia. Efisiensi penggunaan dana BOS akan semakin baik apabila pada tingkat pelaksanaannya dilaksanakan dan digunakan oleh orang-orang yang memiliki modal manusia yang baik. Indikator ini menjadi proxy bagi kualitas penduduk secara makro.

Tingkat kemiskinan Miskini merupakan salah satu bagian yang menentukan lantaran kemampuan rumah tangga untuk mengakses pendidikan. Semakin tinggi tingkat kemiskinan yang terjadi maka semakin tidak efisien dampak

${ }^{5}$ Afonso, A., Schuknecht, L., dan Tanzi, V., Public Sector Efficiency: an International Comparison (European Central Bank WP Series) hlm. 9 
dari dana BOS. Rendahnya efisiensi tersebut disebabkan oleh keterbatasan kemampuan penduduk miskin untuk mengelola bantuan yang diberikan.

Akses ke fasilitas pendidikan Akses $_{i}$ adalah rasio antara luas area per $\mathrm{km}^{2}$ terhadap jumlah sekolah jenjang pendidikan tertentu di suatu daerah. Rasio ini menjelaskan cakupan wilayah per sekolah sebagai indikator infrastruktur untuk mencapai sekolah. Semakin tinggi angka rasio tersebut menandakan semakin sulit seseorang untuk mengakses pendidikan karena semakin tinggi biaya perjalanan yang diperlukan untuk mengakses sekolah.

Sementara variabel dummy pulau menjelaskan identitas dari masing-masing pulau dan pada model penelitian ini akan menggunakan pulau jawa sebagai basis (Jawa=0).

\section{HASIL PENELITIAN}

\subsection{Statistik Deskriptif}

Sebelum memasuki analisis mengenai hasil perhitungan DEA dan metode estimasi tobit, penulis menggambarkan secara ringkas mengenai variabel-variabel kunci yang digunakan. Adapun nilai rata-rata dari variabel kunci yang digunakan tercantum pada Tabel 3.

Tabel 3 Nilai rata-rata variabel kunci penelitian 2014-2017

\begin{tabular}{lcc}
\hline Variabel & SD & SMP \\
\hline Dana BOS (Juta rupiah) & 259342.48 & 123690.68 \\
Dana BOS (\% PDRB) & 9.41 & 4.59 \\
APM (\%) & 96.2 & 75.7 \\
Angka melanjutkan (\%) & 75.69 & 98.09 \\
Guru layak (\%) & 77.57 & 88.04 \\
Jumlah sekolah & 4462 & 1143 \\
Putus sekolah (\%) & 0.3762 & 0.6015 \\
Ruang kelas baik (\%) & 26.27 & 27.94 \\
$\begin{array}{l}\text { Akses sekolah } \\
\text { (Km²/sekolah) }\end{array}$ & 21.88 & 76.68 \\
\hline \hline
\end{tabular}

Sumber: hasil olahan penulis menggunakan data dari Kementerian Pendidikan dan Kebudayaan dan Badan Pusat Statistik.

Alokasi pengeluaran dana BOS pemerintah untuk jenjang SD lebih besar dibandingkan dengan alokasi untuk jenjang pendidikan SMP. Hal tersebut dilakukan karena jenjang pendidikan dasar merupakan fondasi utama pendidikan dini masyarakat dan menjadi bekal utama untuk melanjutkan ke tingkat yang lebih tinggi. Untuk enrollment ratio, APM SD lebih tinggi dibandingkan dengan SMP. Pada dasarnya hampir seluruh masyarakat Indonesia menganggap pendidikan dasar merupakan hal yang penting. APM SMP yang lebih rendah menunjukkan bahwa terdapat sekitar $24.3 \%$ penduduk berusia jenjang pendidikan SMP (13-15 tahun) yang sedang tidak menduduki pendidikan SMP. Hal tersebut kemungkinan disebabkan oleh rendahnya akses untuk menjangkau tingkat pendidikan SMP, melihat setiap SMP perlu mencakup wilayah seluas $77 \mathrm{~km}^{2}$ sementara SD yang hanya perlu mencakup $22 \mathrm{~km}^{2}$. Cakupan wilayah ini menyebabkan biaya transportasi menuju sekolah yang lebih tinggi untuk jenjang pendidikan SMP dibandingkan dengan jenjang pendidikan SD.

Meskipun demikian, data pada Tabel $\mathbf{3}$ menunjukkan bahwa kualitas pendidikan SMP lebih tinggi dibandingkan dengan kualitas pendidikan SD. Beberapa variabel yang mendukung adalah persentase jumlah guru layak mengajar, angka melanjutkan, persentase ruang kelas berstatus baik yang lebih tinggi. Khusus untuk variabel angka melanjutkan untuk SMP yang lebih tinggi dibandingkan SD, hal ini dapat menjadi indikasi bahwa ketika peserta didik sudah dapat melanjutkan ke tingkat SMP, maka kemungkinan besar mereka akan mampu melanjutkan ke SMA/sederajat. Akan tetapi, angka putus sekolah SMP lebih tinggi dibandingkan dengan angka putus sekolah di jenjang pedidikan SD. Angka putus sekolah yang cenderung lebih tinggi pada tingkat SMP tersebut kemungkinan disebabkan oleh kebutuhan biaya bersekolah di jenjang pendidikan SMP yang lebih tinggi dibandingkan dengan jenjang pendidikan SD.

\subsection{Hasil Data Envelopment Analysis}

Hasil perhitungan DEA pada Tabel 4 menjelaskan bahwa secara variable return to scale tingkat efisiensi penggunaan dana BOS baik pada jenjang pendidikan SD maupun SMP sudah relatif efisien. Sementara tingkat efisiensi constant return to scale masih jauh dari efisien. Hal ini menjelaskan bahwa terdapat perbedaan karakteristik yang sangat beragam antarprovinsi di Indonesia, di mana hampir seluruh provinsi tidak beroperasi pada tingkat yang optimum. Dengan demikian, penelitian ini hanya akan fokus kepada hasil efisiensi teknis berdasarkan asumsi variable return to scale.

Tabel 4 Nilai efisiensi teknis perhitungan DEA Indonesia

Rata-Rata Std. Deviasi

$\begin{array}{lll}\text { SMP } & & \\ \text { VRS_TE } & 0.996738 & 0.0028062 \\ \text { CRS_TE } & 0.033564 & 0.0928567\end{array}$


SD

\begin{tabular}{lll} 
VRS_TE & 0.997468 & 0.0026261 \\
CRS_TE & 0.085096 & 0.1371436 \\
\hline
\end{tabular}

Sumber: olahan penulis

Nilai rata-rata efisiensi teknis perhitungan DEA dengan asumsi variable return to scale pada Tabel 5 menjelaskan bahwa Provinsi DKI Jakarta merupakan provinsi yang dapat mengelola penyelenggaraan dana BOS yang paling efisien baik di jenjang pendidikan SD maupun SMP, sementara Provinsi Aceh paling efisien atau setara dengan Provinsi DKI Jakarta pada jenjang pendidikan SMP.

Tabel 5 Rata-rata efisiensi teknis hasil perhitungan DEA VRS 2014-2017

\begin{tabular}{|c|c|c|}
\hline & SD & SMP \\
\hline Aceh & 0.996597 & 1 \\
\hline Sumatera Utara & 0.99633 & 0.99813 \\
\hline Sumatera Barat & 0.997847 & 0.998181 \\
\hline Riau & 0.99668 & 0.997688 \\
\hline Jambi & 0.996118 & 0.996138 \\
\hline Sumatera Selatan & 0.996563 & 0.998122 \\
\hline Bengkulu & 0.996676 & 0.99647 \\
\hline Lampung & 0.99768 & 0.995684 \\
\hline Kep Bangka Belitung & 0.997655 & 0.995836 \\
\hline Kepulauan Riau & 0.99945 & 0.999366 \\
\hline DKI Jakarta & 1 & 1 \\
\hline Jawa Barat & 0.997709 & 0.994978 \\
\hline Jawa Tengah & 0.999022 & 0.997748 \\
\hline D.I Yogyakarta & 0.999199 & 0.999927 \\
\hline Jawa Timur & 0.998994 & 0.997334 \\
\hline Banten & 0.997944 & 0.996024 \\
\hline B A L I & 0.99985 & 0.999927 \\
\hline Nusa Tenggara Barat & 0.997861 & 0.996412 \\
\hline Nusa Tenggara Timur & 0.997199 & 0.992462 \\
\hline Kalimantan Barat & 0.996786 & 0.995137 \\
\hline Kalimantan Tengah & 0.998748 & 0.995253 \\
\hline Kalimantan Selatan & 0.997564 & 0.997795 \\
\hline Kalimantan Timur & 0.997421 & 0.997715 \\
\hline Sulawesi Utara & 0.998611 & 0.997796 \\
\hline Sulawesi Tengah & 0.996129 & 0.996757 \\
\hline Sulawesi Selatan & 0.996111 & 0.99502 \\
\hline Sulawesi Tenggara & 0.994875 & 0.99422 \\
\hline Gorontalo & 0.996768 & 0.99661 \\
\hline Sulawesi Barat & 0.995314 & 0.992576 \\
\hline Maluku & 0.998404 & 0.996385 \\
\hline Maluku Utara & 0.995006 & 0.994394 \\
\hline Papua Barat & 0.998823 & 0.997823 \\
\hline Papua & 0.996494 & 0.994426 \\
\hline Indonesia & 0.997468 & 0.996737 \\
\hline
\end{tabular}

\subsection{Hasil metode estimasi tobit}

Peneliti membandingkan dua metode sebagai robustness check antara estimasi panel data tobit dengan estimasi pooled tobit. Perbedaan diantara kedua model tersebut adalah bahwa data bersifat panel yang berarti mengasumsikan bahwa setiap unit produksi sama setiap tahunnya, sementara pooled merupakan data time series namun tidak semerta-merta unit produksinya sama. Berdasarkan hasil estimasi pada Tabel 6, dapat disimpulkan bahwa model yang digunakan sudah dapat diterima (robust) karena menunjukan signifikansi variabel yang konsisten.

Berdasarkan hasil metode estimasi tobit tersebut, ditemukan jumlah provinsi yang telah menggunakan dana BOS secara efisien (tingkat efisiensi bernilai 1) pada periode periode 20142017 lebih banyak pada tingkat SMP dibandingkan 
Irsyan Maududy dan Abrar Aulia

Tabel 6 Hasil perhitungan regresi tobit

\begin{tabular}{|c|c|c|c|c|c|c|c|c|}
\hline & \multicolumn{2}{|l|}{ Panel tobit } & \multicolumn{2}{|l|}{ Pooled Tobit } & \multicolumn{2}{|l|}{ Panel tobit } & \multicolumn{2}{|l|}{ Pooled Tobit } \\
\hline & SD & SMP & SD & SMP & SD & SMP & SD & SMP \\
\hline $\begin{array}{l}\text { Guru layak } \\
\text { (Prob }>t \text { ) }\end{array}$ & $\begin{array}{l}0.0000618^{* *} \\
(0.020)\end{array}$ & $\begin{array}{c}0.0001502^{* * *} \\
(0.002)\end{array}$ & $\begin{array}{l}0.0000618^{* *} \\
(0.022)\end{array}$ & $0.0001155^{* * *}$ & $\begin{array}{l}0.0000975^{* * *} \\
(0.004)\end{array}$ & $0.0001775^{* * *}$ & $\begin{array}{l}0.0000975^{* * *} \\
(0.004)\end{array}$ & $0.0001668^{* * *}$ \\
\hline Pertumbuhan PDRB & .0000936 & 0.000024 & 0.0000936 & 0.0000106 & 0.000087 & 0.0000691 & 0.000087 & 0.0000855 \\
\hline Tingkat kemiskinan & $-0006411^{* * *}$ & -0.0004531 & $-0.0006411^{* * *}$ & -0.0003309 & $-0.0004536^{* *}$ & $-0.0004901 *$ & $-0.0004536^{* *}$ & $-0.0003973^{*}$ \\
\hline $\begin{array}{c}\text { Tingkat kemiskinan^2 } \\
\text { (Prob }>t)\end{array}$ & $\begin{array}{c}0.0000293^{* * *} \\
(0)\end{array}$ & $\begin{array}{c}0.0000262^{* *} \\
(0.015)\end{array}$ & $\begin{array}{c}0.0000293^{* * *} \\
(0)\end{array}$ & $\begin{array}{c}0.0000207^{* *} \\
(0.012)\end{array}$ & $\begin{array}{c}0.0000224^{* *} \\
(0.013)\end{array}$ & $\begin{array}{c}0.0000286^{* *} \\
(0.013)\end{array}$ & $\begin{array}{c}0.0000224^{* *} \\
(0.014)\end{array}$ & $\begin{array}{c}0.0000244^{* *} \\
(0.012)\end{array}$ \\
\hline IPM $\quad($ Prob $>$ t $)$ & $\begin{array}{c}0.0003836^{* * *} \\
(0)\end{array}$ & $\begin{array}{c}0.0007325 \text { *** } \\
(0)\end{array}$ & $\begin{array}{c}0.0003836^{* * *} \\
(0)\end{array}$ & $\begin{array}{c}0.0007002^{* * *} \\
(0)\end{array}$ & $0.000375^{* * *}$ & $0.0007248^{* * *}$ & $0.000375^{* * *}$ & $0.0007006^{* * *}$ \\
\hline $\begin{array}{r}\text { Cakupan sekolah } \\
\text { (Prob>t) }\end{array}$ & $\begin{array}{c}-0.0000147 \\
(0.279)\end{array}$ & $\begin{array}{c}-3.57 \mathrm{E}-06 \\
(0.484)\end{array}$ & $\begin{array}{c}-0.0000147 \\
(0.281)\end{array}$ & $\begin{array}{c}-2.25 \mathrm{E}-06 \\
(0.563)\end{array}$ & $\begin{array}{c}-0.000023 \\
(0.209)\end{array}$ & $\begin{array}{c}-1.01 \mathrm{E}-05 \\
(0.111)\end{array}$ & $\begin{array}{c}-0.000023 \\
(0.211)\end{array}$ & $\begin{array}{c}-8.73 \mathrm{E}-06 \\
(0.1)\end{array}$ \\
\hline $\begin{array}{r}\text { dummy sumatera } \\
\text { (Prob>t) }\end{array}$ & & & & & $\begin{array}{l}0.0000724 \\
(0.923)\end{array}$ & $\begin{array}{l}0.0022921^{* * *} \\
(0.007)\end{array}$ & $\begin{array}{c}0.0000724 \\
(0.923)\end{array}$ & $\begin{array}{l}0.0021832^{* * *} \\
(0.002)\end{array}$ \\
\hline $\begin{array}{l}\text { dummy bali } \\
\text { (Prob>t) }\end{array}$ & & & & & $\begin{array}{l}0.0011569 \\
(0.257)\end{array}$ & $\begin{array}{c}0.0005718 \\
(0.628)\end{array}$ & $\begin{array}{c}0.0011569 \\
(0.259)\end{array}$ & $\begin{array}{c}0.0005897 \\
(0.540)\end{array}$ \\
\hline $\begin{array}{c}\text { dummy kalimantan } \\
\text { (Prob }>t)\end{array}$ & & & & & 0.0013842 & 0.0021046 & 0.0013842 & $0.0019342^{*}$ \\
\hline $\begin{array}{r}\text { (Prob>t) } \\
\text { dummy sulawesi }\end{array}$ & & & & & $\begin{array}{c}(0.236) \\
0.000142\end{array}$ & $\begin{array}{c}(0.104) \\
0.0008997\end{array}$ & $\begin{array}{c}(0.238) \\
0.000142\end{array}$ & $\begin{array}{c}(0.07) \\
0.0007212\end{array}$ \\
\hline $\begin{array}{r}\text { (Prob>t) } \\
\text { (Prot }\end{array}$ & & & & & $(0.872)$ & $(0.348)$ & $(0.872)$ & $(0.355)$ \\
\hline $\begin{array}{c}\text { dummy maluku papua } \\
\text { (Prob }>t)\end{array}$ & & & & & $\begin{array}{l}0.0028698^{*} \\
(0.052)\end{array}$ & $\begin{array}{l}0.0029256^{* *} \\
(0.035)\end{array}$ & $\begin{array}{l}0.0028698^{*} \\
(0.055)\end{array}$ & $\begin{array}{l}0.0028811^{* *} \\
(0.014)\end{array}$ \\
\hline _cons $\quad($ Prob $>t)$ & $\begin{array}{c}0 . .9687906 \\
(0)\end{array}$ & $\begin{array}{c}0.9344779 \\
(0)\end{array}$ & $\begin{array}{c}0.9693045 \\
(0)\end{array}$ & $\begin{array}{c}0.9392022 \\
(0)\end{array}$ & $\begin{array}{c}0.9651569 \\
(0)\end{array}$ & $\begin{array}{c}0.9313087 \\
(0)\end{array}$ & $\begin{array}{c}0.9651569 \\
(0)\end{array}$ & $\begin{array}{c}0.9334367 \\
(0)\end{array}$ \\
\hline Maximum likelihood & 523.76959 & 492.59988 & 523.76959 & 488.30314 & 527.63863 & 496.79831 & 527.63863 & 494.60369 \\
\hline Pseudo R2 & & & -0.053 & -0.0969 & & & -0.0607 & -0.1111 \\
\hline $\mathrm{N}$ & 132 & 132 & 132 & 132 & 132 & 132 & 132 & 132 \\
\hline Uncensored & 116 & 109 & 116 & 109 & 116 & 109 & 116 & 109 \\
\hline Left-censored & 16 & 23 & 16 & 23 & 16 & 23 & 16 & 23 \\
\hline
\end{tabular}

Sumber: Hasil olahan penulis

Catatan: ${ }^{*}$ ) signifikan pada tingkat kepercayaan $90 \%$; ${ }^{* *}$ ) signifikan pada tingkat kepercayaan $95 \%$; ${ }^{* * *}$ ) signifikan pada tingkat kepercayaan $99 \%$ 
SD $^{6}$. Hal tersebut terlihat dari jumlah unit produksi yang tersensor pada nilai tertinggi (bernilai 1) pada masing-masing model. Pada tingkat jenjang pendidikan SMP terdapat 23 provinsi yang tersensor menandakan selama periode tersebut teradapat 23 provinsi yang memiliki tingkat efisiensi maksimal, sementara jenjang pendidikan SD hanya sebesar 16 provinsi. Walaupun jika melihat secara rata-rata selama 2014-2017 pada tabel 5 menunjukan efisiensi pada tingkat SD lebih tinggi dibandingkan SMP. Hal tersebut menggambarkan variasi tingkat efisiensi yang lebih tinggi pada tingkat SMP. Hasil ini juga konsisten dengan Standar Deviasi VRS pada tingkat SMP yang lebih tinggi dibandingkan tingkat SD (Lihat Tabel 4)

Kualitas pengajar layak atau persentase jumlah guru layak (berpendidikan sarjana atau lebih) merupakan variabel yang signifikan pada tingkat kepercayaan 99\%, ceteris paribus, di setiap jenjang pendidikan. Hal tersebut konsisten dengan premis awal bahwa semakin tingginya kualitas guru maka penggunaan dana BOS dapat semakin efisien karena adanya efisiensi pada tingkat manajerial dana BOS maupun tambahan output relatif terhadap input terhadap guru.

Variabel berikutnya yang signifikan adalah tingkat kemiskinan Miskin. Peneliti menemukan adanya hubungan yang berbentuk $U$-shape pada variabel ini. Hal tersebut terlihat dari pengaruh variabel tingkat kemiskinan dan tingkat kemiskinan yang dikuadratkan. Hal tersebut menjelaskan adanya penurunan marginal return to scale terhadap tingkat efisiensi. Tingginya tingkat kemiskinan pada suatu provinsi menghambat efisiensi penggunaan dana BOS karena pemanfaatan dana tersebut tidak dapat digunakan dengan baik, karena kesulitan masyarakat miskin tersebut untuk menggunakan dananya secara tepat. Di sisi lain, semakin tinggi tingkat kemiskinannya, maka bantuan dana BOS akan semakin memberikan dampak terhadap tingkat efisiensi. Perlu diketahui bahwa dana BOS dihitung berdasarkan tingkat individu peserta didik (Student Unit Cost). Oleh karena itu, penyaluran dana BOS ke daerah yang memiliki tingkat kemiskinan relatif rendah tidak banyak berpengaruh karena dana BOS diterima oleh masyarakat yang relatif tidak miskin, dan cenderung mampu untuk bersekolah di tingkat pendidikan SD maupun SMP dengan biaya sendiri Hal tersebut dapat dilihat pada Gambar 5 dan Gambar 6. Terlihat pada kedua gambar tersebut tingkat kemiskinan memiliki grafik yang berbentuk

\footnotetext{
${ }^{6}$ Perlu dicermati bahwa ada perbedaan penggunaan output pada tingkat SMP dan SD karena perhitungan DEA pada SMP menggunakan tambahan output nilai UN sebagai proxy kualitas pendidikan.
}

U-shape, hal tersebut semakin jelas terlihat pada jenjang pendidikan SD.

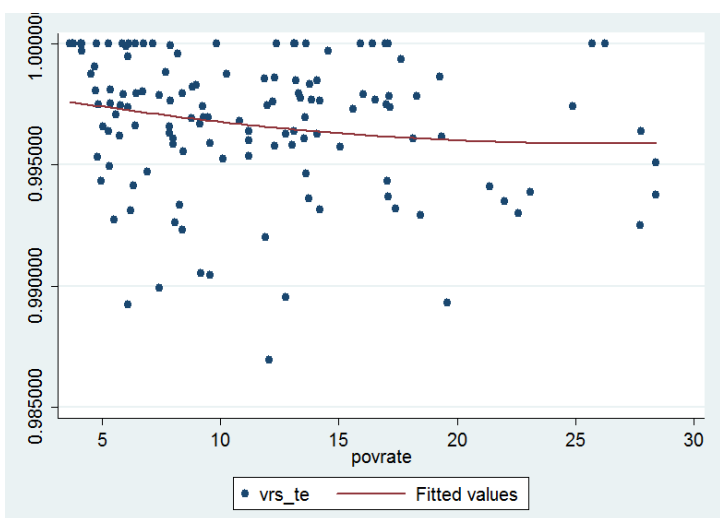

Gambar 5 Pengaruh Tingkat Kemiskinan terhadap Tingkat Efisiensi Pada Jenjang Pendidikan SMP

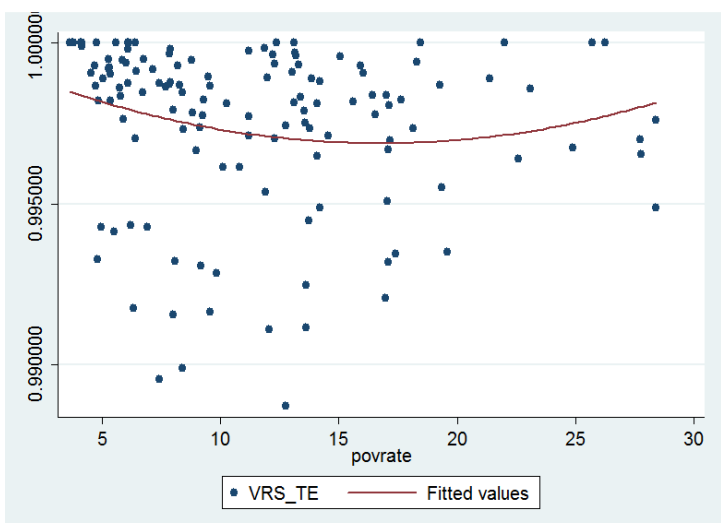

Gambar 6 Pengaruh Tingkat Kemiskinan terhadap Tingkat Efisiensi BOS Pada Jenjang Pendidikan SMP

\section{Sumber: olahan penulis}

Variabel berikutnya yang berpengaruh terhadap tingkat efisiensi penggunaan dana BOS adalah indeks pembangunan manusia IPM. Variabel tersebut konsisten secara signifikan mempengaruhi efisiensi penggunaan dana BOS pada setiap jenjang pendidikan dengan tingkat kepercayaan 99\%, ceteris paribus. Semakin tinggi kualitas hidup masyarakat suatu provinsi membuat penggunaan dana BOS semakin efisien. Hal tersebut terjadi karena kualitas masyarakat secara umum dapat menggunaan dana BOS secara lebih efektif dan efisien. Perlu diketahui bahwa tujuan penyaluran dana BOS adalah meningkatkan tingkat dan kualitas pendidikan secara umum di suatu daerah. Hal tersebut sejalan dengan perhitungan indeks pembangunan manusia yang mana salah satu indikatornya adalah tingkat pendidikan. Sehingga efisiensi penggunaan dana BOS akan sangat dipengaruhi oleh indeks pembangunan manusia.

Variabel pertumbuhan ekonomi dan cakupan sekolah setiap sekolah tidak mempengaruhi 
tingkat efisiensi dana BOS secara signifikan. Meskipun demikian, pengaruh positif variabel pertumbuhan ekonomi konsisten dengan penelitian Fonchamnyo dan Sama (2016) yang menandakan ketika ekonomi tumbuh lebih cepat maka akan meningkatkan efisiensi pada sektor pendidikan. Pengaruh negatif dari variabel cakupan sekolah mengindikasikan semakin tinggi luas wilayah yang dicakup oleh satu sekolah, mengambarkan aksesibilitas yang rendah, menyebabkan tingkat efisiensi penggunaan dana BOS semakin rendah, walaupun variabel ini tidak signifikan.

Melihatnya dari sisi kewilayahan, dengan menggunakan variabel dummy (jawa sebagai basis), secara umum jenjang SD lebih efisien secara rata-rata di luar Pulau Jawa dibandingkan dengan Pulau Jawa walaupun variabel yang signifikan hanya pada Pulau Maluku dan Papua. Meskipun demikian tingkat kepercayaan pengaruh pulau tersebut hanya sebesar $90 \%$, ceteris paribus. Hal ini dikarenakan Pulau Maluku dan Papua yang memiliki tingkat kesejahteraan relatif lebih rendah dibandingkan dengan Pulau Jawa membuat marginal benefit pemberian dana BOS menjadi lebih tinggi dibandingkan dengan Pulau Jawa. Selanjutnya, penerima dana BOS untuk jenjang pendidikan SMP akan semakin efisien relatif terhadap pulau jawa apabila provinsi penerima dana BOS berada di Pulau Sumatera, Kalimantan, dan Maluku dan Papua. Variabel tersebut berpengaruh terhadap tingkat efisiensi secara signifikan 99\%, 90\%, dan 95\% secara berurutan, ceteris paribus. Uji Wald pada setiap model Pooled Tobit dan Panel Tobit menunjukan instrumen dinyatakan sudah valid.

\section{KESIMPULAN DAN SARAN}

Penelitian ini mencoba untuk menganalisis tingkat efisiensi penggunaan dana BOS di 33 provinsi di Inodnesia pada periode 2014-2017. Akibat dari keterbatasan data Provinsi Kalimantan Utara, maka provinsi tersebut tidak diikutsertakan dalam perhitungan dan analisis. Secara umum tingkat efisiensi pada jenjang pendidikan SD dan SMP sudah cukup efisien. Penelitian ini menemukan bahwa Pulau Jawa memiliki tingkat efisiensi yang paling rendah dibandingkan dengan pulau lain, meskipun demikian Provinsi DKI Jakarta (SD dan SMP) dan Aceh (khusus untuk jenjang pendidikan SD) merupakan provinsi yang paling efisien dalam penggunaan dana BOS.

Hasil perhitungan estimasi tobit, menjelaskan bahwa variabel kualitas pengajar yang mana merupakan salah satu tujuan dari disalurkannya dana BOS memiliki dampak yang paling tinggi mempengaruhi tingkat efisiensi. Selanjutnya tingkat kemiskinan memiliki hubungan terhadap tingkat efisiensi yang berbentuk $U$-shape. Variabel lain yang signifikan mempengaruhi efisiensi dana BOS adalah Indeks Pembangunan Manusia (IPM) yang menunjukan pengaruh yang positif. Hal ini menunjukan kualitas modal manusia yang semakin baik membuat efisiensi penggunaan dana BOS yang terhadap output juga semakin baik. Variabel lain dalam model, yaitu pertumbuhan ekonomi dan cakupan sekolah menunjukan hasil yang tidak signifikan, walaupun menunjukan pengaruh yang sesuai dengan hipotesis awal.

Dari kesimpulan tersebut, peneliti menyarankan beberapa kebijakan berikut ini. Pertama, hasil statistik deskriptif menunjukan bahwa jenjang SMP memiliki angka APM yang lebih rendah dibandingkan jenjang SD. Secara bersamaan, sulitnya akses untuk mencakup pendidikan pada jenjang SMP dibandingkan SD dapat menjadi salah satu penyebab (setiap SMP perlu mencakup wilayah seluas $77 \mathrm{~km}^{2}$ sementara SD yang hanya perlu mencakup $22 \mathrm{~km}^{2}$ ). Dalam menunjang wajib belajar 9 tahun, peneliti menyarankan agar adanya kebijakan terintegrasi antara akses pendidikan pada tingkat SD dan SMP. Contohnya, kebijakan jumlah yang sama antara SD dan SMP setiap area tertentu atau pendirian sekolah satu atap antara SD dan SMP. Kedua, melihat tingkat APM SMP yang masih jauh dari target wajib belajar 9 tahun, dengan peningkatan dana BOS setiap tahunnya, maka tambahan anggaran dari tahun sebelumnya diprioritaskan untuk tingkat SMP. Ketiga, penilitian ini menunjukan signifikansi pengaruh variabel guru layak mengajar yang merupakan proxy kualitas guru dan kepala sekolah terhadap efisiensi dana BOS. Jika pemerintah ingin meningkatkan efisiensi penggunaan dana BOS agar outputnya tercapai, kebijakan mengenai peningkatan kualitas guru dan kepala sekolah, khususnya tingkat pendidikan mereka, juga harus dilakukan secara paralel.

Keempat, adanya variasi tingkat efisiensi penggunaan dana BOS setiap provinsi, khususnya pada tingkat SMP yang memiliki standar deviasi yang relatif lebih tinggi dibandingkan dengan tingkat SD, mengharuskan pemerintah pusat meningkatkan perhatian beberapa provinsi yang masih memiliki tingkat efisiensi yang relatif rendah. Saran terakhir, pemerintah perlu mempertimbangkan jumlah dana BOS yang dialokasikan berdasarkan tingkat kemiskinan setiap wilayah tertentu karena alokasi dana BOS terbukti memberikan marginal benefit yang lebih tinggi terhadap provinsi yang memiliki tingkat kemiskinan yang relatif lebih tinggi.

\section{IMPLIKASI DAN KETERBATASAN}

Salah satu keterbatasan penelitian ini adalah kemungkinan terdapatnya permasalahan 
endogeneity. Hal tersebut terjadi karena efisiensi pengeluaran pemerintah mempengaruhi perkembangan tingkat pendidikan di suatu daerah, namun di sisi lain, tingkat pendidikan merupakan salah satu faktor yang menyebabkan terjadinya efisiensi pengeluaran pemerintah akibat dari respon yang lebih baik di masyarakat. Namun, penelitian in telah memberikan adanya hubungan antara kedua hal tersebut.

Selain itu, penelitian ini mengasumsikan dana BOS terhadap persentase PDRB suatu daerah untuk menghilangkan efek besaran ekonomi terhadap efisiensi dana. Akan tetapi, metode tersebut memiliki bias terhadap jumlah penduduk. Hasil penelitian ini menemukan bahwa daerah yang memiliki jumlah penduduk relatif sedikit cenderung lebih efisien dalam penggunaan dananya. Oleh karena itu, akan lebih menarik apabila penelitian berikutnya dapat memperhitungkan efek dari jumlah penduduk terutama jumlah siswa yang menerima dana BOS dengan mengubah variabel dana BOS menjadi dana BOS per siswa di masing-masing provinsi. Penelitian ini juga memiliki keterbatasan akses data, khususnya proxy kualitas pendidikan pada tingkat SD karena tidak tersedianya data nilai UN SD per provinsi yang dikumpulkan secara nasional.

Peniliti menyarankan penelitian selanjutnya untuk menggunakan variasi variabel determinan dari efisiensi penggunaan dana BOS, seperti Indeks Demokrasi setiap provinsi sebagai proxy institusi di masyarakat atau Indeks Persepsi Korupsi sebagai proxy kualitas institusi pemerintahan daerah. Determinan lain yang dapat dilakukan oleh penelitian selanjutnya adalah infrastruktur, seperti panjang jalan yang tidak rusak, untuk melihat kemudahan akses pendidikan. Peneliti juga menyarankan perlunya analisis lebih lanjut mengenai kontribusi dari dana bantuan sosial lainnya dan kontribusi dana dari pemerintah daerah (dari pendapatan asli daerah) yang diberikan pada periode 2013-2017 terhadap output pendidikan.

\section{DAFTAR PUSTAKA}

Afonso, A., Schuknecht, L., \& Tanzi, V. (2003). Public Sector Efficiency: An International Comparison. ECB Working Paper, No. 42, European Central Bank (ECB), Frankfurt a. M.

(2008). Income Distribution Determinants and Public Spending Efficiency. ECB Working Paper, No. 861, European Central Bank (ECB), Frankfurt a. M.

Aziz, A. (2009). Analisis Efektivitas Banun Operasional Sekolah (BOS) Pada Departemen
Pendidikan Nasional. Kajian Ekonomi dan Keuangan, 13(2), 87-110.

Banker, R.D., Charnes, A., \& Cooper, W.W. (1984). Some Models For Estimating Technical And Scale Inefficiencies In Data Envelopment Analysis. Management Science, 30, 1078-1092.

Becker, Gary S. (1975). Investment in Human Capital: Effects on Earnings. The National Bureau of Economic Research. 13-44

Benhabib, J., \& Spiegel, M. M. (1994). The role of human capital in economic development evidence from aggregate cross-country data. Journal of Monetary economics, 34(2), 143-173.

Casu B. \& Molyneux P. (2016). Determinants of Public Spending Efficiency in Education and Health: Evidence from Selected CEMAC Countries. Journal of Economics and Finance, 40, 199-210.

Charnes, A., Cooper, W.W., \& Rhodes, E. (1978). Measuring the Efficiency of Decision Making Units. Journal of Operational Research, 2, 429444.

Departemen Pendidikan Nasional. (2003). UndangUndang RI No.20 tahun 2003 tentang Sistem Pendidikan Nasional. Jakarta, DKI: Departemen Pendidikan Nasional. Diakses dari

http://jdih.kemdikbud.go.id/new/public/asse ts/uploads/dokumen/UU_tahun2003_nomor0 20.pdf

Fonchamnyo, D. C., \& Sama, M.C. (2016). Determinants of Public Spending Efficiency in Education and Health: Evidence from Selected CEMAC Countries. Journal of Economics and Finance, 40, 199-210.

Gavurova, B., Kocisova, K., Belas, L., \& Krajcik, V. (2017). Relative efficiency of government expenditure on secondary education. Journal of International Studies Vol, 10(2).

Gupta, S. \& Verhoeven, M. (2001). The Efficiency of Government Expenditure Experiences from Africa. Journal of Policy Modeling, 23, 433-467.

Hanushek, E. A., Wößmann, L., Jamison, E. A., \& Jamison, D. T. (2008). Education and economic growth. Education Next, 8(2).

Kementrian Pendidikan dan Kebudayaan RI. (2017). Peraturan Menteri Pendidikan Dan Kebudayaan Republik Indonesia Nomor 26 Tahun 2017 Tentang Perubahan Atas Peraturan Menteri Pendidikan Dan Kebudayaan Nomor 8 Tahun 2017 Tentang Petunjuk Teknis Bantuan Operasional Sekolah. Jakarta, DKI: Penulis. Diakses darihttps://psma.kemdikbud.go.id/index/ho 
me/lib/files/pengumuman/permendikbud\% 20no\%2026\%20tahun\%202017-1.pdf

Majelis Permusyawaratan Rakyat RI. (2002). Undang-Undang Dasar Republik Indonesia Jakarta, DKI: MPR RI. Diakses dari http://www.dpr.go.id/jdih/uu1945

Mankiw, N. G., Romer, D., \& Weil, D. N. (1992). A contribution to the empirics of economic growth. The quarterly journal of economics, 107(2), 407-437.

OECD (2017), PISA 2015 Results (Volume III): Students' Well-Being, PISA, OECD Publishing, Paris.

http://dx.doi.org/10.1787/9789264273856en

Psacharopoulos, G. (1981). Returns to Education: An Updated International Comparison. Comparative Education, 17, 321-341.

Psacharopoulos, G. \& Woodhall, M. (1985). Education for Development. Oxford University Press. 313.

Romer, P. M. (1990). Endogenous technological change. Journal of political Economy, 98(5, Part 2), S71-S102.

Rosser, A., \& Joshi, A. (2013). From user fees to fee free: The politics of realising universal free basic education in Indonesia. The Journal of Development Studies, 49(2), 175-189.

World Bank. (2015, 28 May). Assessing the Role of the School Operational Grant Program (BOS) in Improving Education Outcomes in Indonesia. http://documents.worldbank.org/curated/en /779451468253241136/pdf/AUS4133REVISED-WP-PUBLIC-Box391467B-BOSReview-Main-Report-28May2015.pdf

World Bank, Human Capital Project (2018). Human Capital Index Atlas method [Data file]. http://www.worldbank.org/en/publication/h uman-capital 